\title{
Implementation of Problem-Based Learning to Critical Thinking Ability in School: A Systematic Literature Review
}

\author{
Hana Maharani Fahimah ${ }^{1}$, Trisno Martono ${ }^{2}$ \\ Khresna Bayu Sangka ${ }^{3}$ \\ \{hanamfahimah@gmail.com ${ }^{1}$,trisnomartono@fkip.uns.ac.id², b.sangka@gmail.com $\left.{ }^{3}\right\}$
}

Economic Education Sebelas Maret University ${ }^{123}$

\begin{abstract}
The curriculum 2013 encourages critical thinking skills that has a purpose of learning and must be achieved to the education. This research aims to claim the trend of implementation abilities of critical thinking skills in learning at school. The method in this research is a systematic literature review (SLR) study. This research indicates that this trend was initially apparent after its first application of the Indonesian government using a scientific approach. But in fact, Problem Based Learning (PBL) approaches and critical thinking capabilities are incompatible with the context of education. So, the SLR is verifying the essential implementation of the PBL in sharpening the capability of the data on online research from 2009-2018. This systematic review concludes that the following methodological and based literature of key and current literature is necessary. Those research will support scientific comm problem-based learning cities and practitioners for the PBL method and critical of studying.
\end{abstract}

Keywords: problem-based learning, critical thinking ability, implementation, systematic literature review (SLR)

\section{Introduction}

One of the most critical cognitive skills that the industrial sector is vital thinking ability (KKNI). Essential thinking ability is necessary to solve various complex problems that can provide innovation to create an advantage. Facing the global rivalry era, educators in the world constantly focusing their attention on the valuable study strategy growing critical thinking ability of students. The Indonesian government also always ensures the capacity of goodminded principals must have by high school students. But in fact, not all the educators have a consciousness of the strategy growing critical thinking ability of students. Even most educated participants haven't felt the way they were taught in school, not allowing any applications to think critically [1]. One of theapproaches of the teaching that the government suggested as the principal's critical minds of the school's critical minds are the fundamental lessons of Problem Based Learning (PBL) [2]. The government also continues to attempt to increase the quality of education in Indonesia. One of the ongoing agendas is developing the curriculum development, including the development of the judüystem. The model of judgment used 
now is the 2013 curriculum that has adopted the international standard assessment model. One of the characters is more stressed to think critically. The concept is to be strengthened with the previous education purposes but more directed to the formation of the education capabilities. To think critical, creative, creative and innovative, and innovative capabilities as well as able to solve more complexproblems in a challenge which he will face in education [3].

Education is expected to produce a generation capable of dealing with the challenges and problems it faces, especially the preparation of future generations and characterful, agile, skilled, critical, and creative. In line with the concept of educational skills in the 21 st century, according to Raizen's team focused on four categories, namely ways of thinking (creativity, critical thinking, problem-solving, decision making, learning, and innovation), ways of working, or how to work ( comm problem-based learningication and collaboration), tools for working or working tools (I.C.T. and information literation/digital literacy), living in the world (citizenship, life, andcareer, personal and social responsibility) [4] are in line with the case in the problem-basedlearning try of Indonesia, Critical thinking skills have become an essential part as learning goals to be achieved in the world of education, as stated in Permendikbud No. 73 problems based learning 2013 tentang Kerangka Kualifikasi Nasional Indonesia (KKNI). Critical minds of critical thinking capabilities have been developed and conventional schools from a high level, middle and high [3]. Learning is an attempt to lead students to learn the goal of learning process according to the expected [5].

Regardless of the various problem-based learning excess, most educators are reluctant to apply the problem-based learnings in learning process, and even educators tend to do it reluctantly. As for research/research states that great educators prefer to use traditional methods of memorial/conventional and a direct approach of teaching as well asproblem-based Learning [26].

Therefore, this research will focus on implementing the development method of development capabilities critical, which is the problem-based learnings. A question that can be asked is whether problem-based learning is effective means to implement or grow the critical minds of the educated participants.

\section{Research Methods}

This research using the systematic literature method. Systematic Literature Review is literature review that follows a series of basic rules to identify and synthesize research and a matter of judgment to what the subject is known to the subject of the study [23]. This systematic review can provide a significant donation, allowing the policy to compose an approach based on weighing research information and identifying a gap in the following research. Research articles are selected through a database of various types of journals based on keywords used.Keywords used in the search Problem based learning/problem-based learning, critical thinking skills/analytical skills/critical thinking for students in SMA/SMK/MAN in Indonesia. For thepurpose of obtaining the latest study, the search has been limited between 2009 and 2018. The criteria are as follows: (a) an observational study that observes the implementation of PBL and measures changes in the level of critical thinking ability, (b) study targeting implementation issues based in Indonesia (c) studies that are written in English and Indonesian language.

A total of 13 studies have been selected to be analyzed based on the four steps in 
systematic literature review analysis.The figure 1 have shown the four steps in systematic literature review analysis based on [6]. For the first step which is framing a question. For framing an answerable question in a systematicliterature review, the researcher used the PICO framework. PICO is an acronym for "Participant-Intervention-ComparatorOutcomes". In this research paper, participant refers to individualsor population of interest to researcher. Intervention needs to be as broadly or as narrowly defined keepingonly the intervention of researchers' interest. Comparator refer to either the intervention versus placeboor interventions versus conventional treatment or interventions and no treatment are compared. Theoutcome that researcher is interested can be narrowly or broadly defined based on the objective of theliterature review analysis. The outcome is narrowly defined, then literature review analysis is only restrictedto that outcome. The researcher is interested to find out if strategy to increase the critical thinking skills in problem-based learning isenhancing students' achievement.

The second step which is run a search of the literature databases. After the researcher have decided the PICO, the researcher conducted a search of the literature databases. For the third step which is selected the articles for literature review analysis by reading titles, abstracts andfull texts. The researcher set up a scheme where the researcher decided to select and reject the articles forliterature review analysis. For example, the article is relevant for the study question, the article does notdiscuss the outcome that is of interest to this research and the article is published outside of the daterange. Because of that only 22 articles have been chosen to be analysed. For the last step is abstract theinformation from articles. In this matter, the researcher abstract the information from articles and thenput all those needed information into table synthesis matrix according to subthemes: authors, research objective, sample or respondent, research design, analysed data and the findings. From that table analysis, the researcher can make some similarities and differences in the 13 studies.

\section{Results and Discussion}

Through the search on the online article database, has been problem-based learning over 25 articles. On 25 articles are then read again to 13 scripts with the consideration of the abstract contents with the conditions of theuse. At 22 of these scripts, read full texts and acquire several 13 manuscriteries that match all the critically determined. The process we illustrate in the following chart: 


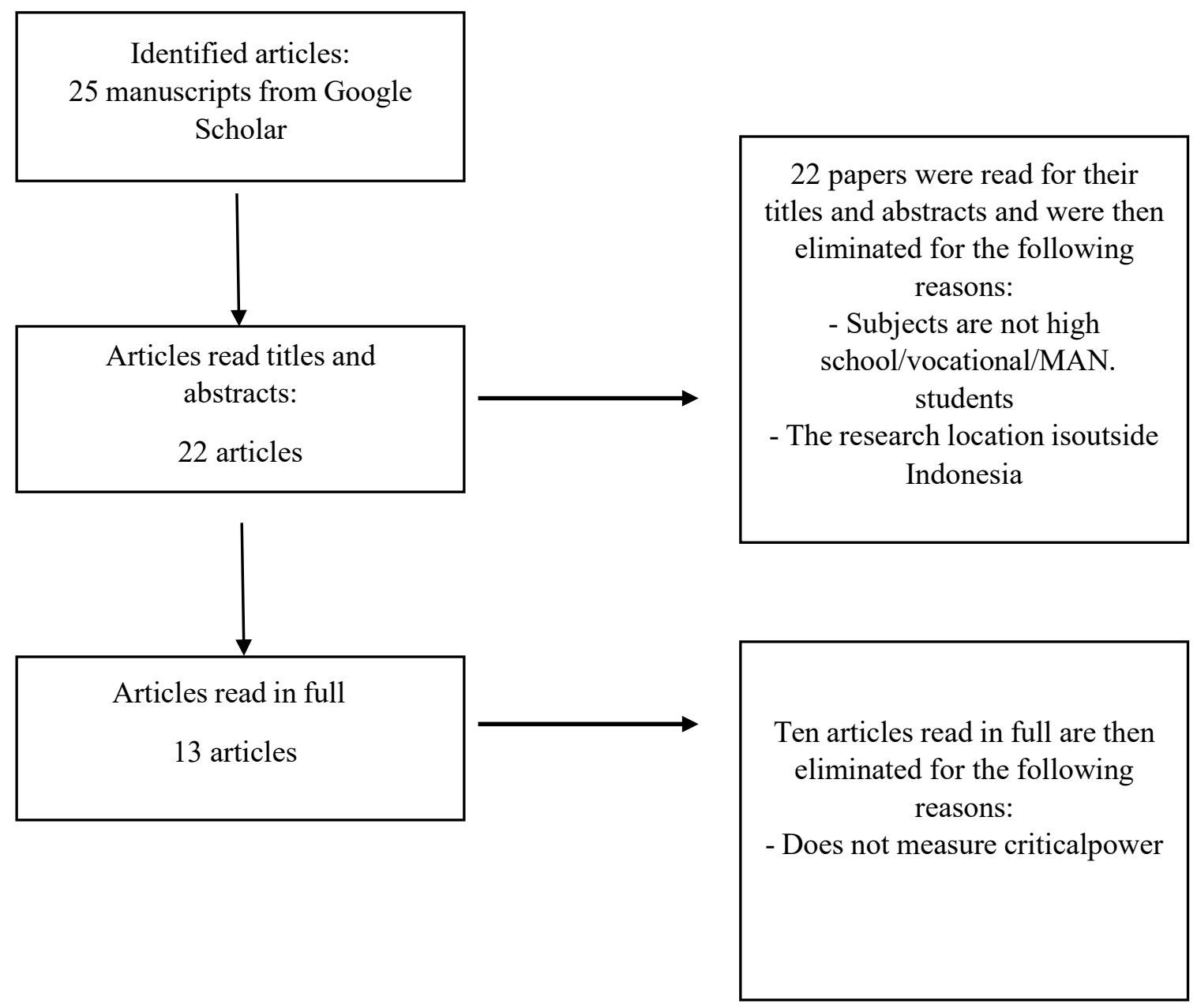

Picture 1. Process of identification study 


\begin{tabular}{|c|c|c|c|}
\hline Number & $\begin{array}{c}\text { Name, } \\
\text { Year }\end{array}$ & Tittle & The Methods of Learning, Problem, and Research Subject \\
\hline 1 & $\begin{array}{l}\text { (Anggraini } \\
\text { etal., 2020) } \\
{[7]}\end{array}$ & $\begin{array}{l}\text { Peningkatan Hasil } \\
\text { Belajar Kognitif Biologi } \\
\text { Melalui Problem Based } \\
\text { Learning Pada Siswa } \\
\text { Kelas X SMA Negeri } 1 \\
\text { Bulu Sukoharjo }\end{array}$ & $\begin{array}{l}\text { The problem that occurred is the low biology study and root } \\
\text { of its problem at biology learning that is not according to the } \\
2013 \text { curriculum. So the solution is classic research by usinga } \\
\text { PBL model. } \\
\text { Data and data sources are from students made subjects of } \\
\text { research and biological subjects. }\end{array}$ \\
\hline 2 & $\begin{array}{l}\text { (Faizah } \\
\text { etal., } \\
\text { 2013) } \\
{[8]}\end{array}$ & $\begin{array}{l}\text { Pengembangan } \\
\text { Perangkat Pembelajaran } \\
\text { Berbasis Masalah } \\
\text { problem based } \\
\text { learningtuk } \\
\text { Meningkatkan Softskill } \\
\text { dan Pemahaman Konsep. }\end{array}$ & $\begin{array}{l}\text { According to observation, about } 70 \% \text { of students still consider } \\
\text { that chemistry is not easy to nail, mainly to solvethe problems } \\
\text { of PBL. Inside chemistry, many formulas and concepts } \\
\text { require a more significant problem-based learning method. } \\
\text { Besides, students consider that the poem is less app-trained, } \\
\text { but only as a theory and a memorial. One of the causes is a } \\
\text { method of learning. } \\
\text { Rejected from the problem, then in needs a creative and } \\
\text { exciting learning device to learn to be more coated and } \\
\text { centered on students and a mena skill set up early.One of the } \\
\text { model Learning is the introductory learning lessonof PBL. } \\
\text { The subject of research is a class of XI-6 science students as } \\
\text { acomprehensive test class, a class XI-7 science students } \\
\text { as a limited test class. }\end{array}$ \\
\hline
\end{tabular}

Design Research and Methods of Research

The kind of research
used is a P.T.K. made up of two cycles

This research method is This research aims to analyze the Research

and validant elevation of learning devices, increase soft skills and forgeries, and student response. The results pointed at the development of a learning device based on the hydraulic that the saltbased material has valid criteria with a 3.57 , there is a soft skill with N-Gain. 
Pengaruh Model

Pembelajaran Berbasis

Masalah Berbantuan

(Munandar Media Animasi

et al, 2018) Terhadap Kemampuan

[9] Berpikir Kritis dan Hasi

Belajar Fisika Siswa

SMAN 5 Mataram

Tahun Ajaran 2016/

2017

Penerapan Model

Problem-Based Learning

untuk Meningkatkan

Keterampilan Berpikir

4

(Lestari Kritis dan Hasil Belajar
During the study process, the teachers should help students actively look for concepts, principles, and facts to themselves, not just give lectures and control classes.

The study process that Teacher-Centered is still in high school

5 Mataram. It's based on the results of observations that have been done in high school 5 Mataram.

To overcome such a necessary study model. One of the models of learning that can be used is a problem-based study model with animated media.

The industry is a pretty partner of students who are prou partners in the Smart Information Surakarta (SMKITSI); it is less creative in completing the work yougive. The industry delivers, when students are given a job to fix the P.C., students have trouble in mending the planes facingP.C. damage, so when determining repairs, that must be in doubt.

All this time, in the process of defense of the seldom of P.C damage that man is given to simple, students also feel difficulty facing the real problem. Through the peddles of critical thinking skills, students will be helped in the process of identifying.

etal.,

Siswa

2017)

[10]

To build critical thinking skills, teachers can give experience study by designing the study process. The teacher prepared the learning by providing the issues that meli $\neg$ batted student's thinking skills and the Meli batting process based on a real problem. One of the applied learning models is the Based

This kind of research is This research aims to know the an experiment

of effect of studying subject-based perfection. problems (PBLM) with animation Experimental research of critical thinking skills and is a way to test the studying high school physics in cause-effects, where 2016/2017.

given treatment to a

particular subject to find its effect.

This research

classroom

research. The subject of study is class $\mathrm{X}$-class competence T.K.Jskills. Data collection uses method observation and work points. Data

acquired analysis is This research aims to increase critical thinking skills and studies critical students and studies for students in the Middle Computer Computer Problem (T.K.J.) in studying P.C. models and research problem-based Learning 
Learning Problem or the problem-based studies.

The subject in this research is a class of XB SMK IT SI, where the students are at the semester of the even-semester of repair material and reclaim P.C. Keterampilan Berpikir Based Learning problems can facilitate critical thinking Kritis Siswa Model Pembelajaran Problem

Virus.

al., 2019) Kemampuan Berpikir

\section{Kritis terhadap}

Kemampuan Berpikir

Tingkat Tinggi students. The specific process in the U.N. theoretically supports the development of essential students according to the applied design (Masek) Yamin, 2011

The research subject is an 11 State High School student ofthe 11 th City, Southern Army of the X-class who is 64 students.

The lack of pro-educated participants in the process of learning to lead to independence, and the process of thinking is not well-understood so it doesn'taccomplish a meaningful study process. The pro competitors experienced certainly results in low learning results (Barus, 2018, P. 18. The development of studying the protégé shows it acquired the average of the determined K.K.M.

This research was performed at ICIP PGRI Pontichild students at a semester II student studies for 34 students.
The type of research is a This research aims to know the rule of experimentation difference of critical thinking that doesn't allow skills of students being taught by researchers to control or models of based Learning Problem manipulate all relevant and Science of the Virus concept

variables except for some variables. (Sugiyono, 2013)

The research method This research aims to know the used as a method of an impact of the impact of model Allocated experiment the problem of the based learning, with a two-way design critical thinking skills, and ANOVA. interaction against the high-level student material of optics 
One of the challenges that the teacher made was to confront the students with problems.

Model Pembelajaran

Berbasis Masalah dan

Pertanyaan Socratik

untuk Meningkatkan

(Rehana Keterampilan Berpikir

,2013a) Kritis Peserta Didik.
As for the evaluation of M.P.S. effectiveness in increasing student's critical skills, models the direct lesson is used as a comparison.

The population in this research is high school students in the Bali Bullet. The number of schools involved in this research is four high schools. Every school was taken two paralle classes, which was class XII
M.P.S. This research is aiming for testing effectiveness in the effectiveness of the model of
increase the skills of learning based problems and thinking critical question Socratic to increase the students are done with skills of students' critical thinking using a domestic skills on science subjects research experiment with a non-equivalent design control group design. a

comparison it's a direct learningmodel.

On the kind of research

of a domestic experiment, the classes that already exist class.

Used in

research. this 


\begin{tabular}{|c|c|c|c|c|c|}
\hline & & Efektivitas Model & According to the research, observation was problem-based & The research method & This research aims to discover the \\
\hline 8 & $\begin{array}{l}\text { Yulianti, } \\
\text { E.(2018) } \\
{[24]}\end{array}$ & $\begin{array}{l}\text { Pembelajaran Problem } \\
\text { Based Learning (PBL) } \\
\text { Terhadap Pemahaman } \\
\text { Konsep Dan Berpikir } \\
\text { Kritis Peserta Didik } \\
\text { SMA }\end{array}$ & $\begin{array}{l}\text { learning problem, which is some studentsdon't listen to the } \\
\text { lessons that are taught by educators (talking to the other } \\
\text { friend, often admitted to the toilet, sleepy, passive, complex } \\
\text { to a understand the concept of matter, and practiced their } \\
\text { critical power in confronting. And the issue of educators, } \\
\text { which is the educator still dominates classes, tends to lecture, } \\
\text { less motivation, and low- volume of educators in matter } \\
\text { delivery. As for the learning model that was capable of } \\
\text { developing and adopted, so the protégé was stationed as the } \\
\text { learning center by applying models study. }\end{array}$ & $\begin{array}{l}\text { was the quasi } \\
\text { Experiment with } \\
\text { pretest-posttest design } \\
\text { control design. The data } \\
\text { of concept and thought } \\
\text { critical is gathered } \\
\text { through the essay test } \\
\text { instruments. }\end{array}$ & $\begin{array}{l}\text { effectiveness of the problem } \\
\text { learning model based Learning } \\
\text { against the idea and critical } \\
\text { thinking of the education High } \\
\text { school on temperature material and } \\
\text { colors. }\end{array}$ \\
\hline 9 & $\begin{array}{l}\text { Yulisman } \\
\text { etal., } 2019 \\
{[14]}\end{array}$ & $\begin{array}{l}\text { Meta Analisis } \\
\text { Implementasi Landasan } \\
\text { Pendidikan dalam } \\
\text { Pengembangan Buku } \\
\text { Siswa Dengan } \\
\text { Menggunakan Model } \\
\text { Problem Based Learning } \\
\text { untuk SMA. }\end{array}$ & $\begin{array}{l}\text { This research is in the X-High-School N1 away of Eastern } \\
\text { Labor, } 70 \text { studentsof the educated. } \\
\text { Education is the education of the student's liberation available } \\
\text { as student books, teaching books that don't use the education } \\
\text { models or by the government is K- } 2013 \text {. } \\
\text { The development of student books is required because the } \\
\text { education of the students' limits in explaining material in } \\
\text { learning material to complete andaiding education models to } \\
\text { meet and aid education models based to contain student's } \\
\text { development of problem should be carrying a basic education } \\
\text { model. }\end{array}$ & $\begin{array}{l}\text { This research uses } \\
\text { ameta-analysis design. } \\
\text { Instruments in this } \\
\text { research use the Human } \\
\text { Instruments. }\end{array}$ & $\begin{array}{l}\text { Developing student books by } \\
\text { using a creative prophecy model- } \\
\text { based learning, it may be possible } \\
\text { to contribute not only to student } \\
\text { understanding and the student's } \\
\text { ability to vary answers soother than } \\
\text { increasing the educational } \\
\text { understanding of its own. }\end{array}$ \\
\hline
\end{tabular}


Model Pembelajaran Berbasis Masalah untuk

Peningkatan

(Rehana Keterampilan

,2013b) Pemecahan Masalah dan

$[15$

Berpikir Kritis
The papers made by each group of the educated participants indicate that the fewer participants were educated appearance solving problems. The educator only uses onesourcebook The pro does not seek another reference to enhance his discussion in the paper. As a result, a debate made by a very shallow participant and strictly follow the sequence of material that exists in one The teacher provided the sourcebook. And according to U.H.'s grades, the grades of the steps and the stages of this pro-up value are still going to need to be repaired and upgraded.The ability of the education can still be enhanced if that learning it was applied to give chance to a pro-educated trainee to use and develop critical thinking skills in the process of solving problems.

Exploring

\section{the}

relationships between

tutor backgroun, tutor

training, and student

based learning meta-

analysis. This research analyzes the gaps in the relationship between research designs with the educational abilities in learning.
The study of class acts was executed in two cycles

Meta-analysis research The primary objective of this

that uses precise
methods and crossdiscipline.

The study of this class acts is iming for increase the skill of solving problems and thinking critical students by applying studies-based problem. research is to expand an attempt to reviewwhat exists by investigating the connection between tutor training, tutor background, and student studying results. 


\begin{tabular}{|c|c|c|c|c|c|}
\hline 12 & $\begin{array}{l}\text { (Sujanem } \\
\text { etal., } \\
\text { 2018) } \\
{[1]}\end{array}$ & $\begin{array}{l}\text { The effectiveness of } \\
\text { problem-based hybrid } \\
\text { learning model in } \\
\text { physics teaching to } \\
\text { enhance critical thinking } \\
\text { of the students of SMAN }\end{array}$ & $\begin{array}{l}\text { The problem that appears is how effective the pro-ball teaching } \\
\text { is. Regarding the low-level high school classes in Bali, } \\
\text { alternative solutions need to be problem-based learning to } \\
\text { train student C.T.s according to the } 2013 \text { curriculum. One } \\
\text { alternative model considered capable of training C.T.s with } \\
\text { the Based Hybrid Learning Problem model. } \\
\text { Model to boost high school students C.T.s The model of the } \\
\text { Based-Hybrid-hybrid Learning (Pro-BHL) which reports that } \\
\text { the study of physics with a pro-the modelin 1st Singarang } \\
\text { model can improve the skill of effectively pre-BHL-hybrid } \\
\text { one st-BHL (Pro-BHL), which reports that the study of } \\
\text { physics with a pro-BHL model from High } 1 \text { Singarang. } \\
\text { This research involves } 86 \text { students divided into three groups } \\
\text { class X. }\end{array}$ & $\begin{array}{l}\text { This research stressed } \\
\text { an analysis of pro- } \\
\text { B.H.L. influence } \\
\text { analysisin the physical } \\
\text { studiesof student C.T.s, } \\
\text { Therefore in this } \\
\text { research used pre- } \\
\text { experimental with pre- } \\
\text { test-test designs and } \\
\text { post-test }\end{array}$ & $\begin{array}{l}\text { This research aims to analyze the } \\
\text { effectiveness of the Based-hybrid } \\
\text { Problem } \\
\text { The pro-BHL research to increase } \\
\text { thecritical thinking ability of high } \\
\text { school students physics lessons. }\end{array}$ \\
\hline 13 & $\begin{array}{l}\text { (Dwi et } \\
\text { al.,2013) } \\
{[16]}\end{array}$ & $\begin{array}{l}\text { Pengaruh Strategi } \\
\text { Problem Based Learning } \\
\text { Berbasis ICT Terhadap } \\
\text { Pemahaman Konsep dan } \\
\text { Kemampuan Pemecahan } \\
\text { Masalah Fisika }\end{array}$ & $\begin{array}{l}\text { Based on observation, that learner of physics still uses the } \\
\text { traditional methods of tradition and has not practical trainingto } \\
\text { solve problems, so the fewer students don't even have any } \\
\text { issues. The design of innovative learning attempts using } \\
\text { effective strategy against concept problem-based } \\
\text { learningderstanding and student matters' capability is } \\
\text { necessary so that the use of an ICT-based PBL strategy will } \\
\text { be adequately supported by the success of the defense of the } \\
\text { defender Yassin (Yassin, Dkk) and contribute to the } \\
\text { achievement of the results of studying desire (Fong Ma, }\end{array}$ & $\begin{array}{l}\text { This research used a } \\
\text { perfectly septic } \\
\text { experiment with a pre- } \\
\text { test-testpost-test control } \\
\text { groupdesign. }\end{array}$ & $\begin{array}{l}\text { This research aims to test the } \\
\text { difference between understanding } \\
\text { of concepts and problem-solving } \\
\text { ability between students who are } \\
\text { learned by using ICT-based U.S. } \\
\text { strategy and students who are } \\
\text { studied withthe PBL strategy. }\end{array}$ \\
\hline
\end{tabular}


2008).

The study process with the ICT-based PBL strategy has a

significant influence on concept understanding and the ability

of the educational problems.

The population is the entire state $\mathrm{X}-\mathrm{X}-1$ st High School student

2012-2013. Sample 72 students divided into two classes taken

with Random Purposive Sample. The instruments used are

grains of concept understanding and the ability to solve

problems in the form of an outline. 


\subsection{The lesson}

The following research results were acquired from 13 journals based on the subject and matter discussed with a model learning subject. Once the analysis of 13 journals, then it's seven subjects and material discussion. The subject of a debate is physics, biology, technology, science, mathematics, automotive, and organization behavior. That three journals discuss physics subjects, and two journals discuss biology subjects. Another lesson is, technology, science, mathematics, automotive, and organization behavior is one journal discussion. Based learning's subject is a subject to a fundamental basic learning problem in increasing the critical ability of students' critical thinking of science. But the lack of influence on social subjects, the vital thinking student's ability to experience a good change after using model problem-based learning [13]. There are increased critical mindset and anxiety in learning progress with problem approaches-based learning. Besides, there's a correlation between the based learning problem syntax with essential indicators of thinking so that the based learning problem can push the critical ability of students [25]. The impact of model problem-based learning can positively affect necessary mindset and study results [17].

\subsection{Research instruments}

While other studies, even though it's not narrow, defines the problem-based learning's approach as solely supplies of problems or cases to students, they also do not adapt other vital components in the issue-based understandings. For example, [7], [7] does not give students a chance to collaborate on cases as [18], social constructive located in the heart of the problem-based learnings approaching students demanding a solution solutive and transaction. Barrows (1986) [19] Argues that the group's work is essential in problem-based learning because one of the primary goals of the problem-based learning approach is developing professional skills of student's future, and working together is one of these skills.

In a world that's more obscures geographic bulbs, collaboration is the key to confront the era of global competition. The teacher must realize this and understand that PBL can be the means to prepare the students to face the global challenges of the future. According to the leading U.B.S. researchers, the role of teachers is far more vital than the role of teachers in the traditional approach [20] and [18]. Teachers in the problem-based learnings approach should be more thorough in social engineering to ensure the nuances of learning that encourage collaboration and display cases that stimulate education's passion.

There seems to be a terrible understanding about the role of situation-based learnings in issue-based learnings. Of twenty studies, only three studies have the correct view of teachers as facilitators in the problem-based understandings. These studies are [21], [22]. While the teacher in the traditional teaching classes is the center of learning where teachers control matter, problems, and procedure solving students, teachers at the issue-based learnings "encourage students with meta-cognitive questions and give explicit directions to what to look for where to find information. The teacher provides an environment of studying central students by pushing independent learning lessons, integration lessons with previous knowledge, interacting with students, and guiding learning process" [2]. Thus, the Problem Based Learning teacher played a guide, not just a pitcher.

As Barrows said [20] and became consensus [18] [2]; the U.S. Walker made up five key elements obligated and supporting each other. Those elements are thelearning-centered on students, teachers as facilitators, actual cases or unstructed, emphasis on long-term professional career skills, and cooperation among the educated experts of the group. 


\section{Conclusion}

This literature review demonstrates the generally positive effect of educational critical thinking ability in PBL. Further research into the various applications of educational technology in PBL curricula is needed to fully realize its potential to enhance problem-based approaches in vocational education and to review aims to assess the implementation ProblemBased Learning (PBL.) in increasingthe critical ability of educated scientific methodology and tested the extent of sound scientific methods. The result of systematic literature reviews identified 22 research that the majority reported a significant influence of the implementation approach learning to the educated analysis of Indonesia.

\section{References}

[1] R. Sujanem, S. Poedjiastuti, and B. Jatmiko, "The Effectiveness of problem-based hybrid learning model in physics teaching to enhance critical thinking of the students of SMAN," J. Phys. Conf. Ser., vol. 1040, no. 1, 2018, doi: 10.1088/1742-6596/1040/1/012040.

[2] H. Leary, A. Walker, B. E. Shelton, and M. H. Fitt, "Exploring the Relationships Between Tutor Background, Tutor Training, and Student Learning: A Problem-based Learning Meta-Analysis," Interdiscip. J. Probl. Learn., vol. 7, no. 1, pp. 3-15, 2013, doi: 10.7771/1541-5015.1331.

[3] I. F. Ahmad and S. Sukiman, "Analisis Higher Order Thinking Skills (Hots) Pada Soal Ujian Akhir Siswa Kelas $6 \mathrm{Kmi}$ Dalam Kelompok Mata Pelajaran Dirosah Islamiyah Di Pondok Modern Tazakka Batang,” J. Pendidik. Agama Islam, vol. 16, no. 2, pp. 137-164, 2019, doi: 10.14421/jpai.2019.162-02.

[4] P. Griffin and E. Care, The ATC21S Method. 2015.

[5] H. Zaini, "Strategi Pembelajaran Aktif," Semin. Lokakarya Nas. Pendidik. Biol. FKIP UNS, vol. 5, no. 1, pp. 1-9, 2016.

[6] A. Gasc et al., “No 主観的健康感を中心とした在宅高齢者における 健康関連指標に関す る共分散構造分析Title,” Photosynthetica, vol. 2, no. 1, pp. 1-13, 2018, [Online]. Available: http://link.springer.com/10.1007/978-3-319-76887-8\%0Ahttp://link.springer.com/10.1007/9783-319-93594-2\%0Ahttp://dx.doi.org/10.1016/B978-0-12-409517-5.000073\%0Ahttp://dx.doi.org/10.1016/j.jff.2015.06.018\%0Ahttp://dx.doi.org/10.1038/s41559-0190877-3\%0Aht.

[7] W. N. Anggraini, A. Purwanto, and A. A. Nugroho, "Peningkatan Hasil Belajar Kognitif Biologi Melalui Problem Based Learning Pada Siswa Kelas X SMA Negeri 1 Bulu Sukoharjo,” IJIS Edu Indones. J. Integr. Sci. Educ., vol. 2, no. 1, p. 55, 2020, doi: 10.29300/ijisedu.v2i1.2864.

[8] Faizah, S. S. Miswadi, and S. Haryani, "Pengembangan perangkat pembelajaran berbasis masalah untuk meningkatkan soft skill dan pemahaman konsep,” J. Pendidik. IPA Indones., vol. 2, no. 2, pp. 120-128, 2013, doi: 10.15294/jpii.v2i2.2712.

[9] H. Munandar, S. Sutrio, and M. Taufik, "Pengaruh Model Pembelajaran Berbasis Masalah Berbantuan Media Animasi Terhadap Kemampuan Berpikir Kritis dan Hasil Belajar Fisika Siswa SMAN 5 Mataram Tahun Ajaran 2016/2017,”J. Pendidik. Fis. dan Teknol., vol. 4, no. 1, p. 111, 2018, doi: 10.29303/jpft.v4i1.526.

[10] D. D. Lestari, I. Ansori, and B. Karyadi, "Penerapan Model Pbm Untuk Meningkatkan Kinerja Dan Kemampuan Berpikir Kritis Siswa Sma,” Diklabio J. Pendidik. dan Pembelajaran Biol., vol. 1, no. 1, pp. 45-53, 2017, doi: 10.33369/diklabio.1.1.45-53.

[11] M. Noprianda, M. F. Noor, and Z. Zulfiani, "Keterampilan Berpikir Kritis Siswa Model Pembelajaran Problem Based Learning Dan Sains Teknologi Masyarakat Pada Konsep Virus," Edusains, vol. 8, no. 2, pp. 182-191, 2019, doi: 10.15408/es.v8i2.3892.

[12] N. Nurhayati, L. Angraeni, and W. Wahyudi, "Pengaruh Model Problem Based Learning, Kemampuan Berpikir Kritis Terhadap Kemampuan Berpikir Tingkat Tinggi,” Edusains, vol. 11, 
no. 1 , pp. 12-20, 2019, doi: 10.15408/es.v11i1.7464

[13] I. W. Redhana, "Model Pembelajaran Berbasis Masalah Dan Pertanyaan Socratik Untuk Meningkatkan Keterampilan Berpikir Kritis Siswa,” J. Cakrawala Pendidik., no. 3, pp. 351-365, 2013, doi: 10.21831/cp.v0i3.1136.

[14] B. P. Yulisman, I. Faradila, and U. Usmeldi, "Meta Analisis Implementasi Landasan Pendidikan dalam Pengembangan Buku Siswa Dengan Menggunakan Model Problem Based Learning Untuk SMA," ... Pembelajaran Fis., vol. 5, no. 1, pp. 81-88, 2019, [Online]. Available: http://ejournal.unp.ac.id/index.php/jppf/article/view/107425.

[15] I. W. Redhana, "Model Pembelajaran Berbasis Masalah untuk Peningkatan Keterampilan Pemecahan Masalah dan Berpikir Kritis,” J. Pendidik. dan Pengajaran, vol. 46, no. 1, pp. 76-86, 2013.

[16] I. M. Dwi, H. Arif, and K. Sentot, "Pengaruh Strategi Problem Based Learning Berbasis Ict Terhadap Pemahaman Konsep Dan Kemampuan Pemecahan Masalah Fisika,” J. Pendidik. Fis. Indones., vol. 9, no. 1, pp. 8-17, 2013, doi: 10.15294/jpfi.v9i1.2575.

[17] M. M. Puspadewi, I. W. Sadia, and P. Yasa, "Penerapan Model Pembelajaran Berbasis Masalah untuk Meningkatkan Hasil Belajar dan Keterampilan Berpikir Kritis dalam Pembelajaran Fisika Siswa Kelas X MIA 2 SMA Negeri 3 Denpasar,” J. Pendidik. Fis. Undiksha, vol. 7, no. 2, pp. 131-140, 2017.

[18] J. . Savery, "Overview Of Problem-based Learning: Devinition and Distinction Interdisciplinary,” J. Probl. Learn., vol. 1, no. 1, pp. 9-20, 2006, [Online]. Available: https://doi.org/10.7771/1541-5015.1002.

[19] H. S. BARROWS, “A taxonomy of problem-based learning methods," Med. Educ., vol. 20, no. 6, pp. 481-486, 1986, doi: 10.1111/j.1365-2923.1986.tb01386.x.

[20] H. Barrows, "Is it truly possible to have such a thing as dPBL?," Distance Educ., vol. 23, no. 1, pp. 119-122, 2002, doi: 10.1080/01587910220124026.

[21] S. Markawira, I. Syah, and S. M, "Penerapan Model Problem Based Learning (Pbl) Dalam Meningkatkan Kemampuan Berpikir Kritis,” J. Pendidik. dan Penelit. Sej., vol. 2, no. 2, pp. 187 204, 2014.

[22] B. F. Rahmawati, "Meningkatkan Motivasi Belajar Dan Kemampuan Berpikir Kritis Mahasiswa Melalui Model Pembelajaran Berbasis Masalah,” Educatio, vol. 8, no. 2, pp. 17-27, 2013, [Online]. Available: http://www.e-journal.hamzanwadi.ac.id/index.php/edc/article/view/5.

[23] Petticrew, M., \& Roberts, H. (2006). Systematic Reviews in the Social Sciences: A Practical Guide. Oxford: Blackwell.

[24] Yulianti, Eka. 2018. Efektivitas Model Pembelajaran Problem Based Learning (PBL) Terhadap pemahaman Konsep dan Berfikir Kritis Peserta Didik SMA. Problem based learningiversitas Islam Negeri.

[25] Khairuntika \& Tina, Y. 2015. Implementasi Model PBL dalam Mengembangkan Kemampuan Berpikir Kritis Peserta Didik. Prosiding Seminar Nasional Matematika dan Pendidikan Matematika, UNY, hal. 333-340.

[26] Martiarini, E. (2016). Developing Students'critical Thinking by Using Problem-Based Instruction Strategy. Journal of English Language Teaching, 1(1), 9-16. 